Research Report No. 18/2011

\title{
The Embedded Firm: Corporate Governance, Labor, and Finance Capitalism
}

Peer Zumbansen

Osgoode Hall Law School of York University, PZumbansen@osgoode.yorku.ca

Cynthia A. Williams

Osgoode Hall Law School of York University, cwilliams@osgoode.yorku.ca

Follow this and additional works at: http://digitalcommons.osgoode.yorku.ca/clpe

\section{Recommended Citation}

Zumbansen, Peer and Williams, Cynthia A., "The Embedded Firm: Corporate Governance, Labor, and Finance Capitalism" (2011). Comparative Research in Law \& Political Economy. Research Paper No. 18/2011.

http://digitalcommons.osgoode.yorku.ca/clpe/56 


\title{
OSGOODE
}

OSGOODE HALL LAW SCHOOL

YOR K UN I VERSITY

\section{OSGOODE HALL LAW SCHOOL}

Comparative Research in Law \& Political Economy

\author{
RESEARCH PAPER SERIES
}

Research Paper No. 18/2011

\section{The Embedded Firm}

Corporate Governance, Labor, and Finance Capitalism

Cynthia A. Williams and Peer Zumbansen

\section{Editors:}

Peer Zumbansen (Osgoode Hall Law School, Toronto, Director, Comparative Research in Law and Political Economy)

John W. Cioffi (University of California at Riverside)

Lisa Philipps (Osgoode Hall Law School, Professor of Law)

Leeanne Footman (Osgoode Hall Law School, Toronto, Production Editor) 


\section{Abstract: The Embedded Firm}

This paper constitutes the introduction to an edited collection, THE EMBEDDED FIRM: Labor, Corporate Governance and Finance Capitalism (Cambridge University Press, 2011). This book brings together contributions from law, economics, sociology and politics in order to evaluate the effects of the shift to shareholder primacy in both the United States and the United Kingdom, in the context of an increasingly financialized economy. Contributors include Ruth Aguilera, William Allen, Harry Arthurs, Blanaid Clark, Mary Condon, Simon Deakin, Sandy Jacoby, William Lazonick, Sue Konzelmann, Dalia Tsuk Mitchell, Larry Mitchell, Frank Wilkinson, and the editors Cynthia Williams and Peer Zumbansen, among others. The book emphasizes empirical evidence, in conjunction with theory, in conscious rejection of the oftstated view that "it takes a theory to beat a theory." For in evaluating the empirical effects of these decades-long trends, in light of the on-going global financial and economic crises—crises propagated from the United States--the problems inherent in American-style corporate governance have become manifest. Such problems do not only concern corporate governance, since the shareholder wealth maximizing norm in the United States is embedded within economic and political institutions stripped of many social democratic norms and policies and with an increasing tendency towards deregulation. But the book demonstrates that the result of shareholder primacy, in conjunction with neo-liberal economic and political norms, has been increasing economic volatility and inequality, systemic fragility, and financial risk that is increasingly being transferred to individuals to manage, given the collapse of many collective bargaining agreements and collective arrangements for pensions. The congruence of theory and evidence suggesting weaknesses in shareholder driven corporate governance as expressed in the U.S. and U.K. give rise to questions of how policy and research can best be harnessed to develop 
more stable systems of corporate governance, and how these goals may best be aligned with government policy. Since it is naïve to think that continental European stakeholder systems, also under pressure, could be transplanted into the United States or the United Kingdom by legislative fiat, the book concludes with suggestions for research and policy development to address the instabilities shareholder corporate governance systems create, while still relying upon existing models within liberal market economies.

Keywords: Corporate governance, financial crisis, labour law, financialization, regulatory reform

JEL: K22, K 31, L20 


\section{The Embedded Firm \\ Corporate Governanœ, Labor and \\ Finanœ Capitalism}

Edited by

Cynthia A. Williams

and

Peer Zumbansen 
CAMBRIDGE UNIVERSITY PRESS

Cambridge, New York, Melbourne, Madrid, Cape Town,

Singapore, São Paulo, Delhi, Dubai, Tokyo, Mexico City

Cambridge University Press

The Edinburgh Building, Cambridge CB2 8RU, UK

Published in the United States of America by Cambridge University Press, New York

www.cambridge.org

Information on this title: www.cambridge.org/9781107006010

(C) Cambridge University Press 2011

This publication is in copyright. Subject to statutory exception and to the provisions of relevant collective licensing agreements, no reproduction of any part may take place without the written permission of Cambridge University Press.

First published 2011

Printed in the United Kingdom at the University Press, Cambridge

A catalogue record for this publication is available from the British Library

ISBN 978-1-107-00601-0 Hardback

Cambridge University Press has no responsibility for the persistence or accuracy of URLs for external or third-party Internet websites referred to in this publication, and does not guarantee that any content on such websites is, or will remain, accurate or appropriate. 


\section{Contents}

List of gures

page viii

List of tables

ix

Notes on contributors

$\mathrm{x}$

1 Introduction: corporate governance after the 'end of history': investigating the new 'great transformation'

CYNTHIA A. WILLIAMS AND PEER ZUMBANSEN

\section{Part I Historical trajectories of business and regulation}

2 Corporate governance and nancial crisis in the long run

SIMON DEAKIN

3 Financialism: a (very) brief history

LAWRENCE E. MITCHELL

4 Legitimating power: the changing status of the board of directors

DALIA TSUK MITCHELL

5 Engaging corporate boards: the limits of liability rules in modern corporate governance

WILLIAM T. ALLEN

6 The primacy of Delaware and the embeddedness of the $\mathrm{rm}$

FENNER STEWART, JR.

7 The new embeddedness of the corporation: corporate social responsibility in the knowledge society

PEER ZUMBANSEN 
Part II New interests, new shareholder constellations, new landscapes

8 Beyond the Berle and Means paradigm: private equity and the new capitalist order

STEPHEN F. DIAMOND

9 Pension funds as owners and as nancial intermediaries: a review of recent Canadian experience SIMON ARCHER

10 Credit derivatives market design: creating fairness and sustainability

JANIS SARRA

11 The EU Takeovers Directive: a shareholder or stakeholder model?

BLANAID CLARKE

12 "Law and nance": inaccurate, incomplete, and important

RUTH V. AGUILERA AND CYNTHIA A. WILLIAMS

\section{Part III Labor's evolution in the new economy}

13 Labor and nance in the United States

SANFORD M. JACOBY

14 The con icting logic of markets and the management of production

SUZANNE KONZELMANN AND FRANK WILKINSON

15 Organizing workers globally: the need for public policy to regulate investment

JOHN EVANS

16 From governance to political economy: insights from a study of relations between corporations and workers HARRY W. ARTHURS AND CLAIRE MUMMÉ

\section{Part IV The transnational embedded rm and the nancial crisis}

17 The intellectual foundations of the global nancial crisis: analysis and proposals for reform

FRANK JAN DE GRAAF AND CYNTHIA A. WILLIAMS 
18 Why executive pay matters to innovation and inequality WILLIAM LAZONICK

19 Products, perimeters and politics: systemic risk and securities regulation

MARY CONDON

20 Modernizing pension fund legal standards for the twenty- rst century

KEITH L. JOHNSON AND FRANK JAN DE GRAAF

\section{Part V Conclusion}

21 Conclusion: evaluation, policy proposals and research agenda

CYNTHIA A. WILLIAMS AND PEER ZUMBANSEN

Index 


\section{Introduction: corporate governance after the 'end of history': investigating the new 'great transformation'}

\section{Cynthia A. Williams and Peer Zumbansen}

Over the last two decades, debates over the convergence or persistence of corporate governance systems have deeply engaged the energies of academics, regulators and investors. These debates have encompassed both the structural mechanisms of corporate decisionmaking, examining where decision-making authority should lie within the company and which groups should have power, as well as the more politically contested issue of whose interests should matter when corporate decisions are being made. How companies are organized, and what powers their constituents have to influence the corporate enterprise - the core questions of corporate governance - in turn influence capital markets and the investment decisions of managers of huge pools of capital. 'Does the country have an equity culture' is often the question asked by investors and asset managers before massive amounts of money are shifted into, or out of, a country at the click of a 'mouse'.

Debates over the convergence or persistence of corporate governance systems take place in the shadow of at least four significant trends affecting operating companies.

First, there is increased global product market competition caused by improvements in information technology, transportation, standardization and supply chain management. These pressures have forced companies in every economy to cut costs, innovate, adopt new business strategies and develop new alliances. The intellectual habits of product and process innovation have also fuelled financial innovation towards similar goals: a search for yield and thus advantage.

Second, we see the transformation of the world's largest corporations from primarily locally- or domestically-situated enterprises into global networks of supply chains and corporate parent/subsidiary relationships. Such enterprises, held together by webs of contracts, law and the interstitial glue of company history and norms, are subject to competing demands from far-flung regulators, consumers, investors, 
non-governmental organizations and professionals such as lawyers, investment bankers and accountants.

Third, undergirding these developments are dramatically increased global capital market pressures throughout the developed and developing world. Newly-engaged market participants; new institutional investors and large pools of investible capital; increasing numbers of shareholders with activist agendas; and new types of nancial innovation and complex nancial engineering have accelerated the transition from industrial to nance capitalism in developed economies. Finance has come to be the dominant contributor to the economic output of such advanced democracies as the United States and Britain, and is of signi cant importance to the productive capacities of countries throughout the world.

Fourth, these trends are situated in a broader context, which is the emergence of the knowledge society, prompting a reconceptualization of public and private forms of governance. Both political and 'private' actors such as non-governmental organizations, corporations, collectives and individuals operate under conditions of extreme uncertainty, both in terms of procedural and institutional design as well as normative horizon. On the one hand, governments and governmental actors have become increasingly dependent on fragmented, societal knowledge, which leads to an important recon guration of the relations between political and civil society actors. The state, in its dependence on constantly updated information, is at the same time implicated in the production of that very information by creating rules and facilitating institutional growth for knowledge production and dissemination. On the other, corporations and other societal actors face pressing governance challenges that in many ways mirror those of contemporary political governing bodies. The dependence of management on expert knowledge, which is generated and communicated both in and outside of the rm, has grown in correlation with the expanding reach of business activities and their impact. With governments and corporations as knowledge actors, producers and consumers, the pressure on law to facilitate and to enable these processes has grown exponentially. No longer clearly situated in an exclusively public or private sphere, 'political', 'private', corporate actors are both authors and receivers of the rules that govern their behaviour.

Given these rapid changes in global operating conditions, it is understandable that there would be pressures on companies to adopt new governance mechanisms in response. Lengthening supply chains, emerging markets such as those in Eastern Europe, Latin America and China becoming part of global production, and increased competition 
all require different managerial arrangements within the $\mathrm{rm}$, at the least. And yet, we argue, the speci c pressures to adopt corporate governance systems that prioritize shareholders' interests - pressures particularly salient in Europe - were as much a product of political ideology as changing economic requirements. In the enclosed chapters we examine those pressures and their effects, both within rms and within societies, evaluating the results of shareholder primacy in light of increasing nancialization not only as a matter of theory, but also as a matter of fact.

\section{Thematic overview}

The following collection addresses, from a historical and comparative perspective, the changing regulatory landscape for business corporations and nancial institutions which has evolved in light of the increasing globalization of the markets and ' nancialization' of economies. Taking their cue from political economy studies of national varieties of market regulation, going back to Karl Polanyi and Andrew Shon eld, the contributing authors explore the effect of integrating markets and converging policy strategies on corporate governance, nance and labour market regulation. The collection brings together authors from law, economics, sociology and political science from both North America and Europe to study the evolution of corporate, nancial and labor regulation against the background of the continuing global economic - and regulatory - crisis.

Inspired by Sanford Jacoby's book The Embedded Corporation, ${ }^{1}$ and by institutional and political economy accounts of corporate governance complementarities, the collected chapters bring a number of disciplinary perspectives to bear to the study of the regulatory evolution and relationship between rms, nance and labour in the transformation from industrial to nance capitalism. Part I of the book traces and evaluates this transformation, connecting it to the nancial crisis that erupted in 2007. Contributions from Simon Deakin and Larry Mitchell provide a theoretical and historical framework for the book as a whole, discussing, respectively, the shift to shareholder primacy and the transformation to nance capitalism in the United States and United Kingdom. Contributions from William Allen, former Chancellor of the Chancery Court in Delaware, and historian Dalia Tsuk Mitchell analyse some of the implications of this transformation

\footnotetext{
${ }^{1}$ Sanford Jacoby, The Embedded Corporation (Princeton: Princeton University Press, 2005).
} 
to nance capitalism on operating companies and their boards of directors, showing the political, historical and sociological forces as work. Fenner Stewart locates these developments within the theoretical debates of leading corporate law scholars today, while Peer Zumbansen provides a broader framework to evaluate the challenges facing both companies and governments within the global knowledge society. Zumbansen's chapter places Polanyi's work on embedded capitalism in the current context of both an intensi ed process of Europeanization and a global search for regulatory remedies against the dramatic market failures since 2007 .

Part II looks more speci cally at particular amalgamations of nancial power that have formed as the transformation to nance capitalism gathered momentum; particular (and particularly destabilizing) nancial instruments; and important regulatory and policy developments in Europe and within international nancial institutions such as the World Bank as pressures mounted to adopt more shareholder friendly corporate governance systems. Stephen Diamond, a contrarian on the nancialization theme, nonetheless evaluates and highlights the growing in uence of private equity investors and hedge funds in the US market. Simon Archer traces changes in the composition, sources of funding and actions within the capital markets of the largest public pension funds in Canada, using that case study as a lens through which to scruitinize the economic role of public pension funds more generally. Janis Sarra discusses credit default swaps and analyses their destabilizing in uence on both nancial markets and bankruptcy proceedings, providing speci c policy advice for regulators to use to address the problems these instruments have caused. Blainaid Clarke's contribution discusses the highly-contested European Takeover Directive, in which the European stakeholder vision of the corporation was supplanted by shareholder-centric rights and pride of place. Her chapter also shows how the political compromises in the Takeover Directive actually operate simultaneously to resist that shareholder perspective. Ruth Aguilera and Cynthia Williams critically evaluate the shareholder bias of noted nance theorists, Rafael La Porta, Florencio Lopez-de-Silanes, Andrei Shleifer and Robert Vishny [commonly referred to as 'LLSV'] from the perspective of economic sociology, while recognizing the important in uence on policy LLSV's theories have had at the World Bank. Collectively these authors bring a legal and political economy perspective to bear to carve out the implications of each of these developments for the balance of power within the $\mathrm{rm}$ and for the distributions of wealth and risk within developed economies. 
There are a number of themes that emerge as we look at the transformation to nance capitalism in Parts I and II. One, which is not unexpected, is that within their different corporate governance structures, labour interests in Europe, the United Kingdom, the United States and Canada have responded to the shift towards nance capitalism in ways characteristic of their home countries' underlying political theories, alliances and power relationships. Thus, labour unions in the United States and Canada have used their pension capital as shareholder activists to advance the interests of their members by using their shareholder voting power, seeking transparency of voting records by their asset managers; board accountability through changes in voting rules; and involvement in limiting executive compensation through the use of shareholder proxy proposals. In these activist uses of pension fund voting power, the expressed corporate governance agenda of labour shareholders has little differed from the corporate governance agenda of shareholder activists generally, including promoting changes in companies' organizing documents that allow the market for corporate control to ourish. Indeed, in an irony little noted in the academic literature (but discussed by Jacoby in this collection), in the United States labour corporate governance activists have been shareholders most consistent advocate. In Europe, labour has used their more integrated political position as recognized social partners to resist efforts to dismantle works councils and co-determination, but have also responded pragmatically in some cases, such as in Germany, as the economic bargains of the post-war era came under increasing pressure from the demands of nance capitalism. In Part III contributions from Harry Arthurs and Claire Mummé discuss these differing uses of labour's shareholding power in North America and Europe, using a political economy analysis, while economist John Evans evaluates labour's voice in international public policy by examining the Trade Union's Advisory Council's position within the OECD.

One of the clearest implications of the shift to nance capitalism has been a corollary insistence that the interests of shareholders should predominate in both corporate governance theory and capital market regulation. A second theme of the book is that the underlying premise asserted in favour of the shareholder model of corporate governance, that such a shift would enhance social welfare, has not been proven. American legal academics Henry Hansmann of Yale University and Reinier Kraakman of Harvard University have been among the most succinct advocates for the view that there will be (and should be) convergence on the shareholder model of corporate governance, as argued in their iconic article from 2001, 'The End of History for Corporate 
Law'. ${ }^{2}$ In that article they posited that shareholder wealth maximizing views of the corporate governance relationship would ultimately predominate throughout the world, by virtue of 'the force of logic, the force of example, and the force of competition'. ${ }^{3}$ As they put the argument in its strongest form, '[ $\mathrm{t}]$ he point is simply that now, as a consequence of both logic and experience, there is convergence on a consensus that the best means to this end - the pursuit of aggregate social welfare - is to make corporate managers strongly accountable to shareholder interests and (at least in direct terms) only to those interests'. ${ }^{4}$ Yet, the premise that shareholder capitalism enhances social welfare has not been seriously examined as an empirical matter by leading corporate law scholars in the United States. Rather, it has been accepted as an article of faith or has been demonstrated by virtue of high share prices.

In Parts III and IV the premise that shareholder capitalism enhances social welfare is, thus, examined empirically, and is found to be unsupported by the evidence. Contributions by leading labour scholars Sanford Jacoby and Harry Arthurs; by industrial relations economists Suzanne Konzelmann and Frank Wilkinson; and by labour economists William Lazonick and John Evans collectively show that pride of place to nance is correlated with increased economic insecurity and inequality; that shareholder capitalism is inconsistent with highly-productive industrial relations; and that investors' short-term demands, ltered through the stock market or through concentrated pools of investment capital, have often undermined companies' long-term planning and investments in research and development to meet future strategic and social challenges. While the Anglo-American venture capital markets permit rapid innovation, the pressures of nance, within shareholder wealth maximizing corporate governance norms, do not produce

${ }^{2}$ Henry Hansmann and Reinier Kraakman, 'The End of History for Corporate Law' (2001) 89 Georgetown Law fournal 439 ('End of History I'). Hansmann and Kraakman further elaborate in a related article, also entitled 'The End of History for Corporate Law', in Jeffrey Gordon and Mark Roe (eds.), Convergence and Persistence in Corporate Governance (Cambridge: Cambridge University Press, 2004) ('End of History II'). It is signi cant that Hansmann and Kraakman reiterated their views of the superiority of American-style shareholder-oriented corporate governance in that collection in 2004, notwithstanding the stock market bubble having burst in the United States, which occurred in 2001-2002, and notwithstanding the serious weaknesses of Enron, WorldCom and many other noted failures of corporate governance in the United Sates during 2001-2002.

${ }^{3}$ Hansmann and Kraakman, 'End of History I', p. 441.

${ }^{4}$ Hansmann and Kraakman, 'End of History II', pp. 42-43. 
companies that show the same capacity for incremental innovation and learning as do European structures. ${ }^{5}$

The third theme of this book, then, engages with the debates over corporate governance systems. The explicit brief of many of these debates has been to determine whether companies are more ef cient and countries more economically successful by prioritizing the interests of shareholders within liberal market economies, rather than balancing the claims of a broader range of stakeholders within coordinated market economies, using the categories introduced by Varieties of Capitalism scholars. ${ }^{6}$ The implicit brief of these debates has challenged European countries and rms, where successful market economies are wellestablished, to adopt Anglo-American shareholder capitalism, even as advocates did their best to export American-style capitalism throughout the developing world. The contribution by Frank Jan De Graaf and Cynthia Williams in Part IV examines the underlying ideological commitments of liberal market corporate governance theory, and challenges Anglo-American theorists to think more carefully about the bene ts of European systems, both for corporate governance arrangements and for capital market regulation. Mary Condon's contribution provides a political economy explanation for international securities regulators' attempts to have greater in uence in transnational regulatory efforts after the global nancial crisis by strategically deploying the concept of 'systemic risk', but also points out regulatory and de nitional problems this concept creates. She also develops the point that securities regulators may need to revisit long-held understandings of the purpose and orientation of disclosure as the preferred regulatory strategy. Part IV concludes with Keith Johnson and Frank Jan De Graaf's recommendations for how understanding of pension funds' duciary duties must evolve to take account of the systemic in uence these important market actors now have.

\section{Theoretical perspectives}

As a general matter, the contributors to this book suggest that what could seem to be politically neutral or merely technical debates about the best systems of corporate governance as a means to the end of creating ef cient, well-run companies and economically successful

\footnotetext{
5 Jacoby, Embedded Corporation, p. 19.

6 Peter Hall and David Soskice (eds.), Varieties of Capitalism: The Institutional Foundations of Comparative Advantage (Oxford: Oxford University Press, 2001).
} 
countries are masking, in fact, serious ideological disagreements. This observation should hardly be surprising, and indeed has been the basis for a respected analysis for why European countries have so far failed to create deep, liquid capital markets. ${ }^{7}$ Nor should the resistance of countries encompassing stakeholder governance systems towards Anglo-American shareholder governance systems be surprising. Inspired by Karl Polanyi and Mark Granovetter as well as by the more recent revival of economic sociology, spearheaded by scholars such as Richard Swedberg and Jens Beckert, we nd that two fundamental dynamics might well explain the persistence of corporate governance systems: the embedded nature of companies, corporate governance systems, and markets, as theorized by Granovetter; and the 'double movement' of market liberalization and resistance, as theorized by Polanyi, who himself is regularly associated with designing a theory of embedded capitalism.

In his article 'Economic Action and Social Structure: The Problem of Embeddedness', ${ }^{8}$ Mark Granovetter brought a sociological and institutional perspective to bear on a fundamental observation: that markets are embedded within the social and political systems in which they arise. Thus, markets cannot be considered free-standing institutions outside of a society, as the 'free market' often had been, and still is in some contexts. Rather 'the market' must be understood as an embedded institution that manifests the social and political values of the society in which it is embedded, including the professional and transnational networks that affect the market, even as it develops its own logic and values. One implication of this view is that corporate governance reforms cannot be considered in isolation from a thorough understanding of the social and cultural context in which companies arise, and in conjunction with a thorough understanding of the complementarities between companies, corporate governance systems, and the political and institutional frameworks in which companies operate. Since stakeholder corporate governance systems are consistent with the social democratic traditions in the countries in which they've arisen - primarily in Northern and Central Europe, but also to some extent in Japan - it would be naïve to expect they would converge to Anglo-American shareholder capitalism smoothly. Even in the face of global product market competition and institutional investor pressure that will in theory privilege the most

7 Mark Roe, 'Modern Politics and Ownership Separation', in Gordon and Roe, Convergence and Persistence pp. 252-290.

8 Mark Granovetter, 'Economic Action and Social Structure: The Problem of Embeddedness' (1985) 91 American Journal of Sociology 481-510. 
ef cient system of corporate organization ${ }^{9}$ - believed by many American law professors to be theirs ${ }^{10}$ - one would expect exactly the persistence of stakeholder systems that is observed, albeit under pressure.

Indeed, Karl Polanyi's work from 1944 on the double movement of market liberalization and resistance predicts this persistence. In The Great Transformation Polanyi argued that as markets expand, so do their undesirable side-effects: instability, monopoly and negative externalities, for instance, and that these side-effects cannot be solved by the market itself. Rather, market expansions are followed by social resistance to 'the pernicious effects of a market-controlled economy'. Polanyi called this the double movement: '[T]he action of two organizing principles in society ... economic liberalism, aiming at the establishment of a self-regulating market ... [and] the other was the principle of social protection aiming at the conservation of man and nature as well as productive organization." 11

The theme of the 'embedded $\mathrm{rm}$ ' that lies at the core of this volume thus reaches back to a signi cant return of economic sociology since the 1980s, notably inspired by Granovetter's seminal article. ${ }^{12}$ The signi cance of this reorientation in research lies in its distinct interdisciplinarity. In contrast to the rise in importance of economics in various elds in law, particularly tort, contract, property and corporate law, ${ }^{13}$ the emerging eld of economic sociology brings together administrative and regulatory studies in the tradition of Max Weber with scholarship in institutional and new institutional economics, such as that by Ronald Coase, Douglass North and Oliver Williamson. ${ }^{14}$ Furthering and

9 A number of academics have recognized that there can be different ways to organize ef cient corporate organizations, and that there can be comparative economic advantage to different corporate governance systems. Jacoby, Embedded Corporation, pp. 170-171: 'The Japanese corporate system - governance, strategy, HR, and much besides - facilitates organizational learning and allows companies to specialize in products and processes that are dif cult for other companies to imitate. By contrast, the U.S. emphases on exibility and mobility require general, not rm-speci c, skills to facilitate rapid allocation of resources to emergent industries.' Jeffrey Gordon and Mark Roe, 'Introduction', in Gordon and Roe, Convergence and Persistence, p. 5 (recognizing the possibility of various paths to ef cient corporate organizations).

10 Hansmann and Kraakman, 'End of History I', p. 441; Hansmann and Kraakman, 'End of History II', pp. 46-48.

11 Karl Polanyi, The Great Transformation: The Political and Economic Origins of Our Time (New York: Farrar \& Rinehart, 1944), p. 132.

12 Granovetter, 'Economic Action and Social Structure'.

13 See generally Richard Posner, Economic Analysis of Law (Boston: Little Brown, 1973), and subsequent editions; Robert Cooter and Thomas Ulen, Law E Economics, 4th edn (Boston: Pearson, 2004).

14 Richard Swedberg, 'The Economic Sociology of Capitalism: An Introduction and Agenda', in Victor Nee and Richard Swedberg (eds.), The Economic Sociology of Capitalism (Princeton: Princeton University Press, 2005). 
expanding the investigative scope of the law and economics agenda, economic sociology has contributed to an increasingly ambitious intellectual discourse about how to organize, govern and regulate corporations across societies. ${ }^{15}$ We recognize this to be another illustration of an encompassing trend towards 'governance studies', which often have their starting point within the framework of a particular discipline but which unfold in an inherently border-crossing manner, drawing on a wealth of different disciplinary perspectives, theoretical foundations and empirical data. ${ }^{16}$

Re ecting on this context, much of the scholarship on comparative corporate governance has been dominated by a law and economics perspective. ${ }^{17}$ Two volumes, one edited by John Armour and Joseph McCahery, ${ }^{18}$ and the other edited by Jeffrey Gordon and Mark Roe, ${ }^{19}$ have attracted considerable attention in enlarging the perspectives on the vivid debate over 'convergence' or 'divergence' in corporate governance principles. Central to all of these volumes, however, is a signi cantly biased perspective from which the policy and regulatory changes within differently observed countries are studied primarily with view to a very small set of established principles of economically theorized, allegedly technical or, 'good' corporate governance, including enhanced investor protection, capital markets disclosure as a primary regulatory mechanism, an absence of employee co-determination and a reduced interventionist role of the state. This credo is signi cantly captured in two landmark monographs, one by Mark Roe from 2003, and one from Kraakman et al. in 2004, that each received both explicit praise and criticism. ${ }^{20}$

15 Ruth V. Aguilera and Gregory Jackson, 'International and Comparative Corporate Governance' (2010) 4 Academy of Management Annals 485-556.

16 Peer Zumbansen, 'The Conundrum of Order. The Concept of Governance from an Interdisciplinary Perspective', in David Levi-Faur (ed.), The Oxford Handbook of Governance(Oxford: Oxford University Press, 2011 forthcoming).

17 See here, above all the following volumes: Klaus J. Hopt, Hideki Kanda, Mark Roe, Eddy Wymeersch and Stefan Prigge (eds.), Comparative Corporate Governance. The State of the Art and Emerging Research (Oxford and New York: Oxford University Press, 1998); Klaus Gugler (ed.), Corporate Governance and Economic Performance (Oxford and New York: Oxford University Press, 2001); Joseph A. McCahery, Piet Moerland, Theo Raaijmakers and Luc Renneboog (eds.), Corporate Governance Regimes. Convergence and Diversity (Oxford and New York: Oxford University Press, 2002); Klaus J. Hopt and Eddy Wymeersch (eds.), Capital Marketsand Company Law (Oxford and New York: Oxford University Press, 2003); Klaus J. Hopt et al. (eds.), CorporateGovernancein Context. Corporations, Statesand M arketsin Europe, Japan and the US (Oxford and New York: Oxford University Press, 2005).

18 John Armour and Joseph McCahery (eds.), After Enron. Improving Corporate Law and Modernising Securities Regulation in Europe and the US (Oxford and Portland: Hart Publishing, 2006).

19 Gordon and Roe, Convergence and Persistence.

${ }^{20}$ Mark Roe, Political Determinants of Corporate Governance (Oxford and New York: Oxford University Press, 2003); evaluated in Peter Gourevitch, 'The Politics 
At the same time, the economic sociology camp has been extremely proli c: led by thinkers such as Wolfgang Streeck at the Max Planck Institute for the Study of Societies in Cologne, Germany, ${ }^{21}$ and by comparative political economists such as Peter Hall and David Soskice, this eld has produced an impressive number of critiques of the 'convergence advocates', convincingly arguing for a more layered perspective on the different dynamics of institutional change with regard to pathdependent, historically evolved corporate governance regimes. ${ }^{22}$ This work has been published in the intellectually rich context of a renewed interest in the 'embeddedness of market institutions', as originally spearheaded by Karl Polanyi, ${ }^{23}$ revived by Granovetter (1985), ${ }^{24}$ before receiving more attention from sociologists and political economists in a volume edited by Rogers Hollingsworth and Robert Boyer ${ }^{25}$ as well as by scholars such as Neil Fligstein. ${ }^{26}$ Related works in this regard have focused on the case of Europe in particular, providing important comparative insights on the different conditions of institutional change and regulatory responses in countries adapting to globally integrated markets, for goods, services, capital and people. ${ }^{27}$

Our collection brings together a diverse group of contributors to challenge the premises of the law and economics perspective with the insights of labour law scholars, economic sociologists and stakeholder

of Corporate Governance Regulation' (2003) 112 Yale Law fournal 1829-1880; Reinier Kraakman, Paul Davies, Henry Hansmann, Gerard Hertig, Klaus Hopt, Hideki Kanda and Edward Rock, The Anatomy of Corporate Law. A Comparative and Functional Approach (Oxford and New York: Oxford University Press, 2004); discussed in David A. Skeel Jr., 'Corporate Anatomy Lessons' (2004) 113 Yale Law fournal 1519-1577.

${ }^{21}$ Wolfgang Streeck, Reforming Capitalism. Institutional Change in the German Political Economy (Oxford: Oxford University Press, 2009).

${ }^{22}$ Wolfgang Streeck, 'German Capitalism: Does It Exist? Can It Survive?', in Colin Crouch and Wolfgang Streeck (eds.), Political Economy of Modern Capitalism (London: Sage, 1997); Wolfgang Streeck and Kozo Yamamura (eds.), The Origins of Nonliberal Capitalism in Germany and fapan: Cornell Studies in Political Economy (Ithaca: Cornell University Press, 2001); Hall and Soskice, Varieties of Capitalism.

${ }^{23}$ Polanyi, The Great Transformation.

${ }^{24}$ See also Mark Granovetter, 'The Impact of Social Structure on Economic Outcomes' (2005) 19 Fournal of Economic Perspectives 33-50.

${ }^{25} \mathrm{~J}$. Rogers Hollingsworth, 'Continuities and Changes in the Social Systems of Production: The Cases of Japan, Germany, and the United States', in J. Rogers Hollingsworth and Robert Boyer (eds.), Contemporary Capitalism. The Embeddedness of Institutions (Cambridge: Cambridge University Press, 1997).

${ }^{26}$ Neil Fligstein, The Architecture of Markets. An Economic Sociology of Twenty-First Century Capitalist Societies (Princeton: Princeton University Press, 2001).

${ }^{27}$ Steven Weber (ed.), Globalization and the European Political Economy (New York: Columbia University Press, 2001); Jonathan Zeitlin and David Trubek (eds.), Governing Work and Welfare in a New Economy: European and American Experiments (Oxford and New York: Oxford University Press, 2003). 
governance experts. Building on the past twenty- ve years of intensive research in the noted elds, the contributors to this volume integrate work done in comparative law, new institutional economics, comparative political economy, regulatory theory, economic sociology and social norms theory in a serious manner. There is no question for these authors that the regulatory landscape of corporate and nancial regulation has changed dramatically in an era of post-welfare state market intervention, marked by indirect regulation, soft law and delegation on the one hand and a dramatically integrated global market on the other. Yet the current challenges of the global nancial crisis give pause, and call for a re-examination of the premises upon which capital market deregulation and the shareholder primacy viewpoint were based.

In this volume, the contributing authors engage with the concept of 'embeddedness' in a context, where the mainstream view - until very recently - sternly defended the demise of effective governmental interventions into market relations. At the present time, the renewed interest in political economy, and the varied histories of regulation and the notion of embedded institutions, re ects on a wide-reaching awareness of the importance of reassessing the foundations of institutional change.

\section{Conclusion}

Written as the nancial and economic crises since 2007 continue to destabilize economies around the world, the social vulnerabilities that have been created by the shift in corporate priorities over the past three decades to short-term shareholders' interests are tragically evident. What is less evident is the way forward, from both a theoretical and policy perspective. Studying the trajectory of the past, in careful detail; developing an analysis of the pressures of nance capitalism and implications of those pressures; and examining views of the $\mathrm{rm}$ with a broader perspective on the interests to be considered, while attending to the conditions necessary for institutional learning, is the task we've set for ourselves. We bring together the enclosed chapters to challenge, to inspire discussion, and to suggest ideas for that way forward, a way that we suggest must better accommodate broader societal interests within the nancial Prometheus that concentrated capital and nancial innovation have unbound. 
Part I

Historical trajectories of business

and regulation 


\section{Conclusion: evaluation, policy proposals and research agenda}

\section{Cynthia A. Williams and Peer Zumbansen}

In this book we've brought together contributions from law, economics, sociology and politics in order to evaluate the effects of the shift to shareholder primacy in both the United States and the United Kingdom, in the context of a parallel shift in both countries to an economy in which nance has an increasingly central role. We have made a decision to include and even emphasize empirical evidence, rather than theory alone, in conscious rejection of the oft-stated view that "it takes a theory to beat a theory." For in evaluating the empirical effects of these decades-long trends in light of the global nancial and economic crises - crises propagated from the United States - we submit that the problems inherent in American-style corporate governance have become manifest. The problem is not only one of corporate governance, since the shareholder wealth maximizing norm in the United States is embedded within economic and political institutions stripped of many social democratic norms and policies. But in conjunction with neoliberal economic and political norms, the result of shareholder primacy has been increasing economic volatility and inequality, systemic fragility and nancial risk that is increasingly being transferred to individuals to manage, particularly given the collapse of many collective bargaining agreements and collective arrangements for pensions.

The congruence of theory and evidence suggesting weaknesses in shareholder driven corporate governance gives rise to questions about what, instead, the goals of corporate governance should be, and how these goals may best be aligned with government policy. It is naïve to think that continental European stakeholder systems could be transplanted into the United States or the United Kingdom by legislative at. As the convergence debate has shown, corporate governance systems are sticky, being deeply embedded in complementary institutional frameworks, political constellations and social norms. Certainly aspects of stakeholder arrangements ought to be studied seriously and mined for their inherent values or regulatory approaches that could inform speci c policy recommendations. But the embedded nature of $\mathrm{rms}$ 
and corporate governance arrangements does suggest caution, and encourages ever more serious, open-minded study in search of policy ideas. The following paragraphs seek to provide some ideas about what topics seem worthy of that further research.

First, as emphasized in a number of chapters, there are examples of both economically liberal economies such as Australia and Canada, and coordinated market economies such as Austria, Belgium, Finland, Germany, Norway and the Netherlands, that have either weathered the global nancial crisis relatively unscathed, or have shown better economic performance than the United States and the United K ingdom over the last decades. (Chapter 13 is particularly instructive on these points, but see also Chapters 12 and 18.) Scandinavian corporate governance systems, as such, are wor thy of greater study, having been relatively ignored in many comparative or international evaluations. M ore generally, evidence-based comparative study of the combinations of corporate governance, government policy and social norms to which these successes are owed would no doubt yield important insights.

One promising approach to developing corporate governance thinking that builds on the Varieties of Capitalism intellectual tradition is to more closely examine varieties of liberalism, as has been done recently by Konzelmann, Fovargue-D avies and Schnyder. ${ }^{1}$ T heir paper addresses the question of why Australian and Canadian banks fared so much better in the global nancial crisisthan did American and British banks, even though all four countries share an English common-law heritage and are market oriented economies. In addition to various government policies that did not permit imprudent mortgage lending or excessive leverage within nancial institutions, the authors point to variations among the type of economic liberalism informing policy generally in Australia and Canada versus the United States and the United Kingdom. They construe Australian and Canadian economic policy as a variation of "ordoliberalism," an approach to economic regulation developed by the German Freiburg school of economists in the early decades of the twentieth century. This school of thought encourages a more active role for government than does laissez-faire liberalism, particularly with respect to inequalities or abuses of power among market actors. Not only is this economic theory worth further exploration and development and has, thus, been attracting attention well beyond the longstanding efforts to conceptualize European legal harmonization,

S. Konzelmann, M. Fovargue-Davies and G. Schnyder, "Varieties of Liberalism" (2010), Centre for Business Research, University of Cambridge, Working Paper No. 403, available at" www.cbr.cam.ac.uk/pdf/WP403.pdf. 
but the concept of "varieties of liberal ism" is an important one for identifying further research trajectories, even as the speci cs of banking (and pension) regulation in Canada and Australia are worthy of further examination.

Second, several of the market developments exposed in the nancial crisis and discussed in this book give rise to further research questions and need for policy development. One, certainly, is the "systemic risk" concern identi ed in Chapter 19, particularly in conjunction with the derivatives market discussed by Sarra in Chapter 10. Various domestic regulatorsand transnational regulatory bodies have been grappling with the implications of this chal lenge, giving rise to a series of questions. "What is systemic risk? How is it created?H ow can it be addressed?' is just the beginning of questions that need attention. More fundamental, we need to ask whether we have reached a level of nancial complexity that is excessive, that is beyond the capacity of nancial market participants themselves or regulators to understand and regulate. Is it simply a matter of distributed knowledge that needs to be mined more effectively by global regulatory "colleges" using better computers, or is there a limit to the types and number of derivative transactions that can be managed effectively in a world of hyper-connectivity and hyperspeed?

Research on systemic risk illustrates the intricate nature of this category of risk, something which is increasingly re ected, on the one hand, in interdisciplinary investigations on the constituting elements that make up systemic risk and, on the other, in an earnest revival of political economy and economic sociology work, as indicated in our introduction to this collection. A de ning trait of this development is the distinct recognition that a better understanding of systemic risk is going to depend in a crucial manner on conceiving of it as a matter of comprehensive social theory, e.g. "governance," rather than through this or that economistic "model." Seen through this lens, the attention attracted by "systemic risk" is ample evidence of a decisive turn to social theory, conducted in an interdisciplinary manner.

Meanwhile, the crucial role of transparency and of "governance by disclosure" is increasingly seen as central to present debates over "good" corporate governance. This is nowhere felt more strongly than in the eld of securities regulation, an area that in many liberal economies has relied primarily on disclosure of $\mathrm{rm}$-speci $\mathrm{c}$ information as the regulatory approach, connecting to views of well-informed, individual rational actors making economically intelligent investment decisions, with the assumption that this is the best way to promote allocational ef ciency. Each of these premises is open to question in 
a world of systemic complexity and multiple redistributions of risk. As discussed in a number of chapters (and even by some regulators), ${ }^{2}$ the premises of market ef ciency, individual rationality leading to market rationality, allocational ef ciency through capital markets, liquidity as always bene cial, even the role of capital markets as "capital providers to rms," need to be re-examined in light of the global nancial crisis and empirical evidence of growing economic fragility, not resilience, in the nancial system. Systems theory and chaos theory from engineering and physics are starting to be deployed to address these questions, which is a promising development. M ore fundamental and comprehensive research into systemic risk, derivatives transactions and complexity is still necessary, however, not only from these scienti c traditions but also from cognitive psychology and regulatory theory.

Chapters 13, 15 and 18 also point to another complex of market developments that needs further research and more sustained policy development, and concerns the implications from trends over the last three decades toward the ever spiraling upward distribution of compensation within the rm, particularly within shareholder driven corporate governance systems. Executive compensation systems designed to "align the interests of managers with the shareholders" as one or even the preferred solution to principal/agent problems, have exacerbated those problems, particularly, as we've seen, within nancial rms. Excessive stock option compensation and bonus-driven compensation have been particularly pernicious in encouraging one-way bets in management's favor and excessive rm-level risk - risk that feeds into the systemic risk issues discussed above. As recognized by Roger $M$ artin, the Dean of the Rotman School of $\mathrm{M}$ anagement in Toronto, Canada, executive compensation needs to be fundamentally re-designed to actually align the interests of management with that of the $\mathrm{rm}$ and itspro tability or revenue, not its stock price. ${ }^{3}$ Lazonick's work with Glimstedt and Xie on Swedish compensation systems provides another promising area of comparative study, ${ }^{4}$ and there are no doubt other comparators valuable for study and to inform more subtle, and effective, policy interventions regarding executive compensation.

2 The Turner Review of 2009, "A Regulatory Response to the Global Financial Crisis," Financial Services Authority (United Kingdom), section 1.4, available at: www.fsa. gov.uk/pubs/other/turner_review.pdf.

${ }^{3}$ Roger $M$ artin, "M anagers M ust Be Judged On The Real Score," Financial Times, M ay 11,2009 , p. 9.

${ }^{4}$ Henrik Glimstedt, William L azonick and $\mathrm{H}$ ao Xie, "T he Evolution and Allocation of Employee Stock Options: Adapting US-style Compensation to the Swedish Business M odel" (2006) 3 European Management Review 156-176. 
Much of the above seems in our view to point directly to the $\mathrm{rm}$ as an entity, the organization and nature of which clearly exceeds its characterization as primarily an investment vehicle. The dramatic regulatory failure of corporate behavior which led to the crisis testi es to the inadequacy of the dominant descriptions of the $\mathrm{rm}$. As alluded to in the introduction and spelled out in more detail in Chapter 7, there is much to be said for an approach which places the $\mathrm{rm}$ in the context of a volatile knowledge society, in which the demarcations between "public" and "private" have become porous and regulatory programs are faced increasingly with the challenge of dealing with constellations of extreme uncertainty. Such uncertainty pertains to the design of organizational frameworks as much as to nding the correct balance between interventionist and facilitative regulation. Uncertainty also pertains to the normative uncertainty of what rms should be allowed to do in a context where large portions of formerly "public" service provision, infrastructure development, nance and maintenance, as well as research and development, have been shifted over to the "private" sector. In this context of transformed statehood, ${ }^{5}$ we need to rethink the fundamentals of our approaches to delineating public from private activity. ${ }^{6}$

Parallel and partially complementing work by scholars such as Lazonick, O'Sullivan or Zumbansen on the "learning" or the "innovative" rm, scholars such as Simon Deakin, Suzanne Konzelmann, Sanford Jacoby, Harry Arthurs but also Paddy Ireland and John Parkinson have been investigating, in particular, the role of the employee within the $\mathrm{rm}$. Today, the disciplinary horizon has been widened even further. As employees within rms increasingly become critical to rms' knowledge bearing and knowledge creating capacities, insights from industrial and organizational psychology need to be brought to bear to connect those important disciplines' research with corporate governance and employment compensation design. Industrial and organizational psychology mechanisms to create high performance workplaces and enhance the justice climates within rms are well-understood in those disciplines, and the productivity gains of various mechanisms supported by extensive empirical evidence from both eld and laboratory studies. This knowledge has been poorly integrated into corporate governance thinking on executive compensation, however, and as such provides fertile ground for interdisciplinary advance.

\footnotetext{
${ }^{5}$ See the interdisciplinary research program at www.sfb597.uni-bremen.de.

${ }^{6}$ For an early, provocative approach, see Bernard de Mandeville, The Fable of the Bes, or Private Vices, Public Bene ts (1714).
} 
Finally, the capital market interventions of pension funds, and the duciary duties of pension fund trustees, need further research and careful policy consideration given the importance of these collective welfare institutions to the health of both societies and capital markets. As Chapters 9, 13 and 20 explore, pension funds of various kinds (public, private and/or labor-oriented) have become key market actors, owning large swathes of the market and becoming invested in every asset class and type of nancial transaction. Given their long-term promises to bene ciariesthey ought to betheultimate patient capitalists. Decades of under-funding by political actors have created acute short-term pressures, however. M oreover, pension funds interact with an entire supply chain of advisors and asset managers whose incentives may not, and often do not, align with the interests of the ultimate bene ciaries. Thus many funds have become anything but patient capitalists. How this situation could be addressed requires a fundamental re-evaluation of the nature of funds' duciary duties, recognizing that funds own the whole market and thus need to be concerned with the health of the whole market and the societies in which they are embedded. M oreover the problems associated with the funds' investment supply chain are well understood, as Chapter 20 discusses. It is time to consider in more detail policy solutions to address those problems. As with each of the topics discussed here, the present collection suggests that such solutions ought to be pursued through a close dialogue between "theory" and "practice." 


\section{Conclusion: evaluation, policy proposals and research agenda}

\section{Cynthia A. Williams and Peer Zumbansen}

In this book we've brought together contributions from law, economics, sociology and politics in order to evaluate the effects of the shift to shareholder primacy in both the United States and the United Kingdom, in the context of a parallel shift in both countries to an economy in which finance has an increasingly central role. We have made a decision to include and even emphasize empirical evidence, rather than theory alone, in conscious rejection of the oft-stated view that "it takes a theory to beat a theory." For in evaluating the empirical effects of these decades-long trends in light of the global financial and economic crises - crises propagated from the United States - we submit that the problems inherent in American-style corporate governance have become manifest. The problem is not only one of corporate governance, since the shareholder wealth maximizing norm in the United States is embedded within economic and political institutions stripped of many social democratic norms and policies. But in conjunction with neoliberal economic and political norms, the result of shareholder primacy has been increasing economic volatility and inequality, systemic fragility and financial risk that is increasingly being transferred to individuals to manage, particularly given the collapse of many collective bargaining agreements and collective arrangements for pensions.

The congruence of theory and evidence suggesting weaknesses in shareholder driven corporate governance gives rise to questions about what, instead, the goals of corporate governance should be, and how these goals may best be aligned with government policy. It is naïve to think that continental European stakeholder systems could be transplanted into the United States or the United Kingdom by legislative fiat. As the convergence debate has shown, corporate governance systems are sticky, being deeply embedded in complementary institutional frameworks, political constellations and social norms. Certainly aspects of stakeholder arrangements ought to be studied seriously and mined for their inherent values or regulatory approaches that could inform specific policy recommendations. But the embedded nature of firms 
and corporate governance arrangements does suggest caution, and encourages ever more serious, open-minded study in search of policy ideas. The following paragraphs seek to provide some ideas about what topics seem worthy of that further research.

First, as emphasized in a number of chapters, there are examples of both economically liberal economies such as Australia and Canada, and coordinated market economies such as Austria, Belgium, Finland, Germany, Norway and the Netherlands, that have either weathered the global nancial crisis relatively unscathed, or have shown better economic performance than the United States and the United Kingdom over the last decades. (Chapter 13 is particularly instructive on these points, but see also Chapters 12 and 18.) Scandinavian corporate governance systems, as such, are worthy of greater study, having been relatively ignored in many comparative or international evaluations. More generally, evidence-based comparative study of the combinations of corporate governance, government policy and social norms to which these successes are owed would no doubt yield important insights.

One promising approach to developing corporate governance thinking that builds on the Varieties of Capitalism intellectual tradition is to more closely examine varieties of liberalism, as has been done recently by Konzelmann, Fovargue-Davies and Schnyder. ${ }^{1}$ Their paper addresses the question of why Australian and Canadian banks fared so much better in the global nancial crisis than did American and British banks, even though all four countries share an English common-law heritage and are market oriented economies. In addition to various government policies that did not permit imprudent mortgage lending or excessive leverage within nancial institutions, the authors point to variations among the type of economic liberalism informing policy generally in Australia and Canada versus the United States and the United Kingdom. They construe Australian and Canadian economic policy as a variation of "ordoliberalism," an approach to economic regulation developed by the German Freiburg school of economists in the early decades of the twentieth century. This school of thought encourages a more active role for government than does laissez-faire liberalism, particularly with respect to inequalities or abuses of power among market actors. Not only is this economic theory worth further exploration and development and has, thus, been attracting attention well beyond the longstanding efforts to conceptualize European legal harmonization,

S. Konzelmann, M. Fovargue-Davies and G. Schnyder, "Varieties of Liberalism" (2010), Centre for Business Research, University of Cambridge, Working Paper No. 403, available at" www.cbr.cam.ac.uk/pdf/WP403.pdf. 
but the concept of "varieties of liberalism" is an important one for identifying further research trajectories, even as the specifics of banking (and pension) regulation in Canada and Australia are worthy of further examination.

Second, several of the market developments exposed in the financial crisis and discussed in this book give rise to further research questions and need for policy development. One, certainly, is the "systemic risk" concern identified in Chapter 19, particularly in conjunction with the derivatives market discussed by Sarra in Chapter 10. Various domestic regulators and transnational regulatory bodies have been grappling with the implications of this challenge, giving rise to a series of questions. "What is systemic risk? How is it created? How can it be addressed?" is just the beginning of questions that need attention. More fundamental, we need to ask whether we have reached a level of financial complexity that is excessive, that is beyond the capacity of financial market participants themselves or regulators to understand and regulate. Is it simply a matter of distributed knowledge that needs to be mined more effectively by global regulatory "colleges" using better computers, or is there a limit to the types and number of derivative transactions that can be managed effectively in a world of hyper-connectivity and hyperspeed?

Research on systemic risk illustrates the intricate nature of this category of risk, something which is increasingly reflected, on the one hand, in interdisciplinary investigations on the constituting elements that make up systemic risk and, on the other, in an earnest revival of political economy and economic sociology work, as indicated in our introduction to this collection. A defining trait of this development is the distinct recognition that a better understanding of systemic risk is going to depend in a crucial manner on conceiving of it as a matter of comprehensive social theory, e.g. "governance," rather than through this or that economistic "model." Seen through this lens, the attention attracted by "systemic risk" is ample evidence of a decisive turn to social theory, conducted in an interdisciplinary manner.

Meanwhile, the crucial role of transparency and of "governance by disclosure" is increasingly seen as central to present debates over "good" corporate governance. This is nowhere felt more strongly than in the field of securities regulation, an area that in many liberal economies has relied primarily on disclosure of firm-specific information as the regulatory approach, connecting to views of well-informed, individual rational actors making economically intelligent investment decisions, with the assumption that this is the best way to promote allocational efficiency. Each of these premises is open to question in 
a world of systemic complexity and multiple redistributions of risk. As discussed in a number of chapters (and even by some regulators), ${ }^{2}$ the premises of market efficiency, individual rationality leading to market rationality, allocational efficiency through capital markets, liquidity as always beneficial, even the role of capital markets as "capital providers to firms," need to be re-examined in light of the global financial crisis and empirical evidence of growing economic fragility, not resilience, in the financial system. Systems theory and chaos theory from engineering and physics are starting to be deployed to address these questions, which is a promising development. More fundamental and comprehensive research into systemic risk, derivatives transactions and complexity is still necessary, however, not only from these scientific traditions but also from cognitive psychology and regulatory theory.

Chapters 13, 15 and 18 also point to another complex of market developments that needs further research and more sustained policy development, and concerns the implications from trends over the last three decades toward the ever spiraling upward distribution of compensation within the firm, particularly within shareholder driven corporate governance systems. Executive compensation systems designed to "align the interests of managers with the shareholders" as one or even the preferred solution to principal/agent problems, have exacerbated those problems, particularly, as we've seen, within financial firms. Excessive stock option compensation and bonus-driven compensation have been particularly pernicious in encouraging one-way bets in management's favor and excessive firm-level risk - risk that feeds into the systemic risk issues discussed above. As recognized by Roger Martin, the Dean of the Rotman School of Management in Toronto, Canada, executive compensation needs to be fundamentally re-designed to actually align the interests of management with that of the firm and its profitability or revenue, not its stock price. ${ }^{3}$ Lazonick's work with Glimstedt and Xie on Swedish compensation systems provides another promising area of comparative study, ${ }^{4}$ and there are no doubt other comparators valuable for study and to inform more subtle, and effective, policy interventions regarding executive compensation.

2 The Turner Review of 2009, "A Regulatory Response to the Global Financial Crisis," Financial Services Authority (United Kingdom), section 1.4, available at: www.fsa. gov.uk/pubs/other/turner_review.pdf.

3 Roger Martin, "Managers Must Be Judged On The Real Score," Financial Times, May 11,2009 , p. 9.

${ }^{4}$ Henrik Glimstedt, William Lazonick and Hao Xie, "The Evolution and Allocation of Employee Stock Options: Adapting US-style Compensation to the Swedish Business Model” (2006) 3 European Management Review 156-176. 
Much of the above seems in our view to point directly to the $\mathrm{rm}$ as an entity, the organization and nature of which clearly exceeds its characterization as primarily an investment vehicle. The dramatic regulatory failure of corporate behavior which led to the crisis testi es to the inadequacy of the dominant descriptions of the $\mathrm{rm}$. As alluded to in the introduction and spelled out in more detail in Chapter 7, there is much to be said for an approach which places the $\mathrm{rm}$ in the context of a volatile knowledge society, in which the demarcations between "public" and "private" have become porous and regulatory programs are faced increasingly with the challenge of dealing with constellations of extreme uncertainty. Such uncertainty pertains to the design of organizational frameworks as much as to nding the correct balance between interventionist and facilitative regulation. Uncertainty also pertains to the normative uncertainty of what rms should be allowed to do in a context where large portions of formerly "public" service provision, infrastructure development, nance and maintenance, as well as research and development, have been shifted over to the "private" sector. In this context of transformed statehood, ${ }^{5}$ we need to rethink the fundamentals of our approaches to delineating public from private activity. ${ }^{6}$

Parallel and partially complementing work by scholars such as Lazonick, O'Sullivan or Zumbansen on the "learning" or the "innovative" rm, scholars such as Simon Deakin, Suzanne Konzelmann, Sanford Jacoby, Harry Arthurs but also Paddy Ireland and John Parkinson have been investigating, in particular, the role of the employee within the $\mathrm{rm}$. Today, the disciplinary horizon has been widened even further. As employees within rms increasingly become critical to rms' knowledge bearing and knowledge creating capacities, insights from industrial and organizational psychology need to be brought to bear to connect those important disciplines' research with corporate governance and employment compensation design. Industrial and organizational psychology mechanisms to create high performance workplaces and enhance the justice climates within rms are well-understood in those disciplines, and the productivity gains of various mechanisms supported by extensive empirical evidence from both eld and laboratory studies. This knowledge has been poorly integrated into corporate governance thinking on executive compensation, however, and as such provides fertile ground for interdisciplinary advance.

\footnotetext{
${ }^{5}$ See the interdisciplinary research program at www.sfb597.uni-bremen.de.

${ }^{6}$ For an early, provocative approach, see Bernard de Mandeville, The Fable of the Bes, or Private Vices, Public Bene ts (1714).
} 
Finally, the capital market interventions of pension funds, and the duciary duties of pension fund trustees, need further research and careful policy consideration given the importance of these collective welfare institutions to the health of both societies and capital markets. As Chapters 9, 13 and 20 explore, pension funds of various kinds (public, private and/or labor-oriented) have become key market actors, owning large swathes of the market and becoming invested in every asset class and type of nancial transaction. Given their long-term promises to bene ciaries they ought to be the ultimate patient capitalists. Decades of under-funding by political actors have created acute short-term pressures, however. Moreover, pension funds interact with an entire supply chain of advisors and asset managers whose incentives may not, and often do not, align with the interests of the ultimate bene ciaries. Thus many funds have become anything but patient capitalists. How this situation could be addressed requires a fundamental re-evaluation of the nature of funds' duciary duties, recognizing that funds own the whole market and thus need to be concerned with the health of the whole market and the societies in which they are embedded. Moreover the problems associated with the funds' investment supply chain are well understood, as Chapter 20 discusses. It is time to consider in more detail policy solutions to address those problems. As with each of the topics discussed here, the present collection suggests that such solutions ought to be pursued through a close dialogue between "theory" and "practice." 